\title{
PIG FARMING PERFORMANCES OF THREE PAPUAN TRIBES: CASE STUDY OF BYAK, ONATE AND ARFAK TRIBES IN PAPUA BARAT
}

\author{
D. A. Iyai ${ }^{1}$, O. Marani ${ }^{2}$, T. Marjen ${ }^{3}$ and L. Usior ${ }^{4}$ \\ ${ }^{1}$ Faculty of Animal Sciences Fishery and Marine Sciences, The State University of Papua, \\ Jl. Gunung Salju, Amban, Manokwari 98314, Papua Barat - Indonesia \\ ${ }^{2}$ Livestock and Veterinary Provincial Board of Papua Barat, \\ Jl. Trikora, Wosi 98313, Papua Barat - Indonesia \\ ${ }^{3}$ Agricultural and Livestock Regency Board of Biak, \\ Jl. Selat Madura No.4., Postal code 98117, Papua Province - Indonesia \\ ${ }^{4}$ Agricultural and Livestock Regency Board of Yapen Islands, \\ Jl. Irian, PO Box 132, Papua Province - Indonesia \\ Corresponding E-mail: da.iyai@yahoo.com
}

Received January 06, 2013; Accepted February 23, 2013

\begin{abstract}
ABSTRAK
Penelitian ini bertujuan untuk memahami perbedaan tatalaksana pemeliharaan ternak babi oleh tiga suku besar di Papua, yaitu Byak, Onate dan Arfak. Wilayah penelitian meliputi dua provinsi yaitu Papua dan Papua Barat. Suku-suku di Provinsi Papua yang diamati meliputi wilayah suku Byak di Pulau Biak dan etnis Onate di Pulau Yapen. Sementara di Provinsi Papua Barat diwakili oleh suku Arfak. Lokasi studi di Biak meliputi Distrik Samofa, Kepulauan Yapen di Distrik Yapen Selatan meliputi kampong Famboaman, Anotaurei, Mariadei dan Mantembu. Lokasi studi di Manokwari meliputi Distrik Manokwari Barat pada Kelurahan Wosi. Dengan menggunakan riset partisipasi berupa interview dan observasi sebanyak 105 peternak babi diwawancarai dan di ambil datanya. Analisis data dilakukan dengan Analisis Ragam dan Pearson Chi-square $\left(\chi^{2}\right)$. Hasil penelitian menunjukkan karakeristik peternak relatif sama yang meliputi umur, pendidikan, tujuan beternak dan spesies ternak yang dipelihara. Namun demikian, terdapat beberapa perbedaan dalam hal pengalaman beternak, jumlah ternak yang dipelihara dan jumlah anak sekelahiran. Ransum pakan yang diberikan berbeda. Temuan yang tidak signifikan berbeda adalah pada sumber pakan dan proses pengolahan pakan. Pengetahuan reproduksi ternak dan pengalaman dalam hal manajemen partus pada ternak induk babi relatif sama diantara ketiga etnis Papua. Pengalaman menangani penyakit ternak dan pengetahun pada penyakit menular adalah relatif sama. Secara umum diantara ketiga etnis ini tatalaksana pemeliharaannya relatif sama.
\end{abstract}

Kata kunci: sistim peternakan babi, etnis asli Papua, Byak, Onate, Arfak.

\section{ABSTRACT}

The objective of this study was to depict the pig farming performances of three different native Papuan tribes, i.e. Byak, Onate and Arfak. Sites in Biak were taken from Samofa District. Sites in Yapen were taken from South Yapen District comprised of Famboaman, Anotaurei, Mariadei and Mantembu villages. Site in Manokwari was chosen at Sub-district of Wosi. Participatory research using interview and observation was done towards 105 pig farmers. One-way analysis of variance and Pearson Chisquare $\left(\chi^{2}\right)$ were used to analyse data. Several indicators tested were age, education, objectives of rearing pigs, and species of pigs. The characteristics of pig farmers were similar. The variations of pig farmers' characteristics ware found in pigs' rearing experience, animal number and litter size. Offered feeding on each physiological period was different. Similar finding were feeding sources and feeding process. Reproduction knowledge and their experience in farrowing management are similar amongst the tribes. In general experiences and knowledge to prevent infectious diseases in general were similar. The three tribes have relatively similar in managing their pig farming systems.

Keywords: pig farming systems, Papuan native tribes, Byak, Onate, Arfak. 


\section{INTRODUCTION}

Several experts have estimated that recently ethnics of Papua are more than 250 tribes. Some are recognized having their own traditional agricultural knowledge in managing their livelihood. One of their main livelihoods is raising pigs (Randa, 1994). Other important Papuan livelihood are farming, fishing, hunting and gathering and in few numbers are working as public state officers. Ethnics of Papuan live at coastal, islands, lowland and highland areas. Several dense populations of tribes are Sentani (Jayapura), Dani (Wamena), Mee (Paniai, Dogiyai, Deiyai and Nabire), Muyu and Mindiptana (Merauke), Ayammaru (Sorong), Byak (Biak-Numfor), Onate (Yapen), and Arfak (Manokwari). The three latter are represented both of the Papua province, i.e. Byak and Onate and Papua Barat province is represented by Arfak tribe.

Pigs are worth for the above Papuan tribes and kept for economical purpose and social purposes such as consumption, generating income, festivals and sacred ceremonial (Pattiselanno and Iyai, 2005; Iyai, 2008). Ethnics of Papuan have their own perception, function and values. Perception, functions and values of pigs amongst different tribes are varied. These will determine how their pig farming systems are managed. Therefore, it was assumed that the pig farming systems of the three larger ethnics, both in Papua and Papua Barat provinces, would be different. There are tribes, in the highland Papua, that have strong relationship emotion with the pigs such as Dani and Mee in the central highland of Papua, compared to other tribes such as coastal pig farmers in Papua, e.g. Byak, Onate and Doreri in Manokwari. The rest farmers have kept pigs for other reasons as mentioned above. The variation of perception, function and values has appeared on how piggeries have been managed and how pigs are being treated in the stall. In addition, farmers' knowledge and experience are the two components that are needed as basic guidelines in raising pigs.

Iyai (2008) has identified four pig keeping systems. Not many studies done with defining and comparing pig farming systems. Only few studies had combined several systems of pig rearing between lowland and highland (Randa, 1994) and between palm and penned pig farming systems. The importance of recognizing systems of pig farming that are kept by tribes is to decide what are the resources being used by pig farmers and decisions being made to improve and promote small-scale pig farming systems. Comparing the pattern of pig farming performances and seeking the way pigs are kept will help expert and other related stakeholders to improve the tribes' livelihood as stated by Perkins (2002). Iyai (2008) reported that pigs in Manokwari have already had low productivity compared to those in tropical countries, in which improved pigs are promoted. Examples were drawn in Vietnam (Lemke et al., 2006) and Thailand (Kunavongkrit and Hard, 2000).

The objectives of this study were to measure and compare the performances of pig farmers of the three Papuan tribes, i.e. Byak, Onate and Arfak, particularly performances of farmers, pig farming management and pig herd performances.

\section{MATERIALS AND METHODS}

\section{Site Selections}

These studies were done at Biak, Yapen and Manokwari regency. In Biak, samples were taken from Samofa district, while in Yapen samples were taken from Angkaisera district consisted of several villages, i.e. Famboaman, Anotaurei, Mariadei and Mantembu villages and in Manokwari samples were taken from sub district of Gayabaru.

Biak is located at Cenderawasih bay $0^{\circ} 21^{\prime}-$ $1^{\circ} 31^{\prime}$ South Latitude $134^{\circ} 47^{\prime}-136^{\circ} 48^{\prime}$ East Meridian with altitude of 0-1.000 meter above sea level, Yapen is located at $134^{\circ} 46^{\prime}-137^{\circ} 54^{\prime}$ East Meridian and $01^{\circ} 27^{\prime}-02^{\circ} 50^{\prime}$ 'South Latitude and Manokwari is located at $132^{\circ} 30^{\prime}-134^{\circ} 45^{\prime}$ 'East Meridian and $0^{\circ} 20^{\prime}-2^{\circ} 25^{\prime}$ South Latitude.

\section{Research Approach and Variable Measurements}

Participatory situation analysis (PSA) was applied to approach pig farmers (Conroy, 2005). Interviews using questionnaire was done to collect relevant information from all pig farmers. During collecting data, a number of 105 heads of households as pig farmer participants were interviewed.

Variable measured and observed were age of farmers (y), experience of farmers in rearing pigs (y), animal number/or herd size indicated the number of pigs reared by pig farmers, litter size was indicated by number of born piglets per sow/gilt per farmer, pig species was breeds 
species raised by pig farmers, number of offered feeding was indicated by the amount of feed offered to the pig herd ( $\mathrm{kg} /$ day), feeding sources indicated places where feeds were collected. Types of feeds indicated kinds of feeding offered to pigs, feeding processing was the ways feeds provided, and infectious disease information indicated infectious diseases experienced by pig farmers. Mating systems are the ways sows and gilts are mated, heat detection indicated how farmers experiencing the signs of oestrus, pregnancy diagnosis of sow was the sign of pigs entering the period of gestation, selection procedures were how farmers selecting the high breed pigs, infectious diseases indicated the amount of outbreaks of infectious diseases, knowledge of infectious diseases detection indicated how farmers recognize infectious diseases and prevention was how the farmers prevent and face infectious pig diseases. Data concerning litter size and sold pig were recorded.

Pig production potential (PPP) was calculated as $\mathrm{PPP}=[(\mathrm{M} / \mathrm{PPE}) \mathrm{x} 100]$, where $\mathrm{M}$ is number of growers and mature pigs consumed and/or sold. Pig production efficiency (PPE) was computed by $\mathrm{PPE}=(\mathrm{sum}$ of weaning piglets, grower, sows and boars)/total herd (Chiduwa et. al., 2008).

\section{Data Analysis}

An analysis of one-way Anova (Ott and Longnecker, 2001) was used. Classification was based on the three tribes characteristics consisted of Byak, Onate and Arfak tribes. Statistical model was $\mathrm{Y} i j=\mu+\alpha i+\varepsilon i j$, where $\mathrm{Y}_{i j}$ was variable responses (Snedecor and Cochran, 1989), consisted of age (y), experience, animal number, litter size, pig species, number of offered feeding, feeding sources, type of feeding, feeding process, and infectious disease information. $\mu$ is overall mean, $a_{i}$ is effects of ethnics, i.e. Byak, Onate and Arfak pig farmers, and $\varepsilon_{i j}$ is errors with normal distribution, N (0, I). Duncen's Multiple Range Test was further tested. Pearson Chi-square $\left(\chi^{2}\right)$ test was used to test the association of several qualitative nominal data with regard to pig species, feeding sources, feeding process, mating system, heat detection of sow, pregnancy diagnosis of sow, selection procedures, infectious diseases (knowledge of infectious diseases and prevention). Data were analysed using SPPS version 18.0.

\section{RESULTS AND DISCUSSION}

Knowing and comparing the performances of pig farmers on the basis of tribe population are the utmost important. This is by the reason that every ethnic lives and shares their knowledge, value, experience and perception amongst the pig farmers. Their ages, time when farmer begin to raise pigs, education and non-education and availability of lands determine how the pig farmers behave on their pig farming.

The findings of pig farmer performances at the three native tribes with related to ages, experience, animal number, litter size and reared pig species were shown in Table 1 . There was no difference of ages between the three tribes. The oldest ages were performed by Byak tribe pig farmers (45.29 \pm 9.65 years old) and followed in the narrow range by Onate and Arfak. Byak and Onate tended to have similar number of ages compared to Arfak. It seems that Byak tribe pig farmers were longer in rearing pigs compared to the other two tribes. Byak and Onate are islanders and they are fisherman. In one hand, Arfak pig farmers are specialist of pigs and crops. The average of Kenyan pig farmers (Kagira et al., 2010) was less two years old from Byak and one year old from Onate.

Rearing pigs' experiences of pig farmers were significantly different $(\mathrm{P}<0.05)$. Experiences were found in the Onate pig farmers, i.e. $12.38 \pm 7.56$ years. The shortest experience was shown in Arfak (8.51 years). It seems that the starting years when Arfak reared pigs in the urban areas were in the late of year 1995. While the Byak pig farmers commencing raising pigs were in the late of year 2000. This might be a new settlement of Byak tribe in the era of special autonomy. Kagira et al. (2010) did not mention the experience of pig farmers in terms of the years when raising pigs have been done.

Education levels of pig farming amongst the three tribes was similar $(\mathrm{P}>0.05)$. Little uneducated pig farmers were found at these pig farmers tribes. Junior and senior high school levels were mostly concentrated by these pig farmers. Only a few farmers were found having high educated farmers (university level). Besides, Byak and Onate tended to have similar number of educated farmers compared to Arfak tribe.

The objective of rearing pigs amongst these three tribes was similar. High number of pig farmers from Byak and Onate had run their pig farming on commercial (generate income) 
Table 1. Characteristics of the Three Papuan Pig Farmers in Byak, Onate and Arfak

\begin{tabular}{|c|c|c|c|c|c|c|c|c|c|}
\hline \multirow{3}{*}{ Farmer Performance } & \multicolumn{6}{|c|}{ Three Tribes } & \multirow{2}{*}{\multicolumn{2}{|c|}{ Total $(\mathrm{n}=105)$}} & \multirow{3}{*}{ Prob. } \\
\hline & \multicolumn{2}{|c|}{$\operatorname{Biak}(n=51)$} & \multicolumn{2}{|c|}{ Onate $(n=26)$} & \multicolumn{2}{|c|}{ Arfak $(n=28)$} & & & \\
\hline & Mean & SD & Mean & SD & Mean & SD & Mean & SD & \\
\hline Age (year) & 45.29 & 9.65 & 44.50 & 11.03 & 42 & 10.12 & 44.22 & 10.13 & 0.383 \\
\hline Experience (year) & $6.96^{\mathrm{a}}$ & 7.19 & $12.38^{\mathrm{a}}$ & 7.56 & $9.28^{\mathrm{b}}$ & 8.51 & 8.92 & 7.89 & 0.015 \\
\hline \multicolumn{10}{|l|}{ Education level (\%) } \\
\hline No educated & 2 & 4 & 1 & 3 & 8 & 28 & 11 & 10 & 0.199 \\
\hline Basic & 7 & 13 & 3 & 11 & 12 & 42 & 22 & 21 & 0.199 \\
\hline Junior & 15 & 29 & 8 & 30 & 4 & 14 & 27 & 25 & 0.199 \\
\hline Senior & 20 & 39 & 12 & 46 & 1 & 3 & 33 & 31 & 0.199 \\
\hline University & 7 & 13 & 2 & 7 & 3 & 10 & 12 & 11 & 0.199 \\
\hline \multicolumn{10}{|l|}{ Objective $(\%)$} \\
\hline Commercial & 34 & 67 & 22 & 84 & 2 & 7 & 58 & 55 & 0.199 \\
\hline Semi-commercial & 17 & 33 & 4 & 16 & 26 & 93 & 45 & 42 & 0.199 \\
\hline \multicolumn{10}{|l|}{ Pig species (\%) } \\
\hline Race & 19 & 37 & 16 & 62 & 6 & 21 & 41 & 39 & 0.199 \\
\hline Local & 27 & 52 & 8 & 31 & 18 & 65 & 52 & 50 & 0.199 \\
\hline Crossbred & 6 & 11 & 2 & 7 & 4 & 14 & 12 & 11 & 0.199 \\
\hline
\end{tabular}

Different superscripts among mean value in the same rows shows significant different $(\mathrm{P}<0.05)$

purpose. Arfak had many purposes, i.e. commercial, social cultures and consumption. This is commonly practiced by pig farmers in other Papua region. Similar finding of Kenyan free-range pig farmers was reported by Kagira $e t$ $a l$. (2010) who reported that keeping pigs were for generating income.

There was no association between the breed type preferences amongst the three native tribes $(\mathrm{P}>0.05)$. The majority of pigs raised by pig farmers was local pigs or wild pigs (Sus scrofa), followed by race or local $\times$ crossbred progeny (Sus scrofa $\times$ batam pigs or VDL). In few cases minor number of crossbred were raised by pig farmers, such as Back shire and Landrace.

In free-ranging pig keeping, breeds used are mostly local and crossbreds beside wild (Sus scrofa) and crossed pigs. Local, wild crossed and crossed breeds reared in penned and semi-penned in Manokwari which revealed by Randa (1994) and Iyai (2008). Typical breeds raised in Manokwari are Dutch Landrace (Randa, 1994),
White Landrace and Chinese crossbred. Similar finding was reported under Kenyan smallholder pig farming system, which crossbreed and local breed were reared by pig farmers (Kagira et al., 2010).

\section{Feeding Components}

Feeding is accounted for $70-80 \%$ of the total purchased production (Eusebio, 1980). Feeding pigs in urban versus rural areas are contrasting dependent on prior mentioned resources. The pig keeping systems in urban areas depend on kitchen and disposal or swill-feed (Anil et al., 2006), the so called non-conventional feeds (NCFs) (Udo, 1997) and commercial feed. Moreover, the pig keeping systems in rural areas inevitably consider having abundantly local resources such as crops and residuals. The amount of offered ration at the three tribes was significantly different $(\mathrm{P}<0.01)$. The Arfak had higher amount of offered ration $(9.08 \pm 3.01 \mathrm{~kg} / \mathrm{day})$ compared to Onate and Byak tribes, i.e. $5.69 \pm 1.31 \mathrm{~kg} / \mathrm{day}$ and $2.92 \pm 1.60$ 
Table 2. Feeding Characteristics Applied by the Three Papuan Pig Farmers in Byak, Onate and Arfak

\begin{tabular}{|c|c|c|c|c|c|c|c|c|c|}
\hline \multirow{3}{*}{ Feeding Performance } & \multicolumn{6}{|c|}{ Three Tribes } & \multirow{2}{*}{\multicolumn{2}{|c|}{ Total $(\mathrm{n}=105)$}} & \multirow{3}{*}{ Prob } \\
\hline & \multicolumn{2}{|c|}{ Byak $(n=51)$} & \multicolumn{2}{|c|}{ Onate $(n=26)$} & \multicolumn{2}{|c|}{$\operatorname{Arfak}(n=28)$} & & & \\
\hline & Mean & $\mathrm{SD}$ & Mean & $\mathrm{SD}$ & Mean & $\mathrm{SD}$ & Mean & $\mathrm{SD}$ & \\
\hline $\begin{array}{l}\text { Amount of feeding } \\
\text { on offer }(\mathrm{kg})\end{array}$ & $2.92^{\mathrm{a}}$ & 1.60 & $5.69^{\mathrm{b}}$ & 1.31 & $9.08^{c}$ & 3.01 & 5.25 & 3.27 & 0.000 \\
\hline Piglet (kg) & $0.26^{\mathrm{a}}$ & 0.46 & $0.65^{\mathrm{b}}$ & 0.64 & $1.43^{\mathrm{c}}$ & 0.92 & 0.67 & 0.81 & 0.000 \\
\hline Grower (kg) & $0.95^{\mathrm{a}}$ & 0.95 & $1.88^{\mathrm{b}}$ & 0.92 & $3.07^{\mathrm{c}}$ & 1.38 & 1.74 & 1.39 & 0.000 \\
\hline Adult (kg) & $1.71^{\mathrm{a}}$ & 1.33 & $3.23^{\mathrm{b}}$ & 0.43 & $4.55^{\mathrm{c}}$ & 1.48 & 2.84 & 1.71 & 0.000 \\
\hline \multicolumn{10}{|l|}{ Feeding sources $(\%)$} \\
\hline Paid & 39 & 76 & 26 & 100 & 9 & 32 & 74 & 70 & 0.199 \\
\hline Swill & 14 & 27 & 26 & 100 & 4 & 14 & 44 & 42 & 0.199 \\
\hline Cropland & 21 & 41 & 16 & 61 & 18 & 64 & 55 & 52 & 0.199 \\
\hline \multicolumn{10}{|l|}{ Feeding process $(\%)$} \\
\hline Cooked & & & 11 & 42 & 0 & 0 & 11 & & 0.157 \\
\hline Cut & 48 & 33 & & & & & & & \\
\hline Full & 14 & 10 & & & & & & & \\
\hline Mixed & 11 & 8 & & & & & & & \\
\hline Rape & & & 6 & 23 & 15 & 53 & 21 & & 0.157 \\
\hline Cut & 18 & 18 & & & & & & & \\
\hline Full & 11 & 11 & & & & & & & \\
\hline Mixed & 22 & 22 & & & & & & & \\
\hline Combination (\%) & & & 10 & 38 & 13 & 47 & 23 & & 0.157 \\
\hline Cut & 15 & 15.3 & & & & & & & \\
\hline Full & 1 & 1.2 & & & & & & & \\
\hline Mixed & 34 & 34 & & & & & & & \\
\hline
\end{tabular}

Superscripts differed in the rows shown significant differences (one-way Anova test, $\mathrm{P}<0.05$ ). Percentage is obtained by calculating overall value divided by total counted and multiplied by total respondents $=(48 / 73) * 51$.

kg/day. Feeds were offered differently based on the physiological ages of pigs that showed significantly different $(\mathrm{P}<0.01)$. Offered ration to the piglets were higher offered by Arfak, i.e. $1.43 \pm 0.92 \mathrm{~kg} /$ day and followed by Onate and Byak. Grower's ration offered was significant difference $(\mathrm{P}<0.01)$ applied by the three tribes and still Arfak had higher number of offered ration. Similar finding indeed was on the adult that was significantly different $(\mathrm{P}<0.01)$. Higher mark of feeding on offered was practiced by Arfak tribe, i.e. $4.55 \pm 1.48 \mathrm{~kg} /$ day. Besides, Byak and Onate tended to have similar number of offered ration compared to Arfak.
Data in Table 1 shows that the proportion of offered ration increased when the pig has been reached a mature period. However, it seems that adult pigs offered by ration less than $2 \mathrm{~kg} \mathrm{day}^{-1}$ will cause negative energy balance (NEB). Therefore production and reproduction of pigs reared by the Byak can have significant declined productivity. The ratio of offered ration on piglets and growers applied by Byak and Onate was in danger of pig life. Starvation will then appear and the pigs become weak and die. Similar simulation analysis was reported by Iyai (2009).

There was no association between feeding sources chosen by three native ethnics' pig 
Table 3. Reproduction and Breed Experiences of Pigs Reared by the Three Papuan Pig Farmers in Byak, Onate and Arfak

\begin{tabular}{|c|c|c|c|c|c|c|c|c|c|}
\hline \multirow{3}{*}{$\begin{array}{l}\text { Reproduction } \\
\text { Performance }\end{array}$} & \multicolumn{6}{|c|}{ Three Tribes } & \multirow{2}{*}{\multicolumn{2}{|c|}{ Total $(n=105)$}} & \multirow{3}{*}{ Prob } \\
\hline & \multicolumn{2}{|c|}{ Byak $(n=51)$} & \multicolumn{2}{|c|}{ Onate $(n=26)$} & \multicolumn{2}{|c|}{ Arfak $(n=28)$} & & & \\
\hline & Mean & $\overline{S D}$ & Mean & SD & Mean & SD & Mean & SD & \\
\hline Herd size (head) & $5.39^{\mathrm{a}}$ & 5.40 & $9.42^{\mathrm{a}}$ & 4.79 & $26.82^{b}$ & 30.35 & 12.10 & 18.46 & 0.000 \\
\hline Piglet & $1.61^{\mathrm{a}}$ & 2.46 & $3.27^{\mathrm{a}}$ & 4.45 & $14.25^{\mathrm{b}}$ & 17.47 & 5.39 & 10.78 & 0.000 \\
\hline Grower & $1.67^{\mathrm{a}}$ & 2.53 & $2.96^{\mathrm{a}}$ & 2.48 & $5.61^{b}$ & 7.69 & 3.04 & 4.76 & 0.002 \\
\hline Adult & $2.11^{\mathrm{a}}$ & 2.05 & $3.19^{\mathrm{a}}$ & 1.60 & $6.82^{\mathrm{b}}$ & 10.52 & 3.63 & 5.94 & 0.003 \\
\hline \multicolumn{10}{|l|}{ Oestrus sow (\%) } \\
\hline Yes & 39 & 76 & 18 & 69 & 9 & 32 & 66 & 63 & 0.199 \\
\hline No & 12 & 24 & 8 & 31 & 19 & 68 & 39 & 37 & 0.199 \\
\hline \multicolumn{10}{|l|}{ Mating system (\%) } \\
\hline Natural & 51 & 100 & 26 & 100 & 28 & 100 & 105 & 100 & 0.199 \\
\hline Artificial & 0 & 0 & 0 & 0 & 0 & 0 & 0 & 0 & \\
\hline \multicolumn{10}{|l|}{ Gestating sow (\%) } \\
\hline Yes & 40 & 78 & 22 & 84 & 25 & 89 & 87 & 82 & 0.199 \\
\hline No & 10 & 22 & 4 & 16 & 3 & 11 & 27 & 18 & 0.199 \\
\hline Litter size (head) & $1.61^{\mathrm{a}}$ & 2.46 & $8.96^{\mathrm{b}}$ & 2.63 & $9.61^{b}$ & 2.64 & 5.56 & 4.62 & 0.000 \\
\hline \multicolumn{10}{|l|}{ Sold pigs (head) } \\
\hline Piglet & 3.5 & 1.2 & 4.6 & 2.7 & 5.4 & 2.4 & 4.6 & 2.3 & 0.199 \\
\hline Grower & 2.7 & 1.3 & 3.2 & 1.5 & 3.6 & 1.7 & 2.8 & 1.8 & 0.199 \\
\hline Adults & 1.5 & 1.4 & 1.4 & 1.5 & 2.2 & 2.2 & 1.9 & 1.6 & 0.199 \\
\hline \multicolumn{10}{|c|}{ Selection Procedures (\%) } \\
\hline Yes & 25 & 49 & 16 & 61 & 15 & 53 & 56 & 53 & 0.199 \\
\hline No & 26 & 51 & 10 & 39 & 13 & 47 & 49 & 47 & 0.199 \\
\hline
\end{tabular}

A test was done using Pearson Chi-square $\left(\chi^{2}\right)$.

farmers. Feeding sources were obtained from commercial feed, swill feed and cropland yields. Byak and Onate tribes mostly buy feed crops around $76 \%$ up to $100 \%$. Collecting feed from restaurant and household wastes called by "swill feed" was higher on Onate and Byak and in a minor source collected from croplands applied by $64 \%$ farmers.

There was no association between feeding process amongst the three tribes. Feeding process was done by using three means, i.e. cooked, rape and its combination. Cutting or chopping feeds in small pieces is frequently done in the entire pig farmers. Although, in one occasion, practices by offering full feeding without cutting it were done. Cassava is frequently offered in small pieces. Taro is usually offered into small pieces and as a whole. Taro is cocked beforehand (Iyai, 2008). Similar application of ration was also offered by Indian pig farmers (Kumaresan et al., 2008).

\section{Reproduction and Breed Experiences}

There were significant difference of animal number $(\mathrm{P}<0.01)$ amongst the three native tribes. 
Table 4. Sanitation of Housing and Pigs Reared by the three Papuan Pig Farmers in Byak, Onate and Arfak Tribes

\begin{tabular}{|c|c|c|c|c|c|c|c|c|c|}
\hline \multirow{3}{*}{ Infectious Diseases } & \multicolumn{6}{|c|}{ Three Tribes } & \multirow{2}{*}{\multicolumn{2}{|c|}{ Total $(\mathrm{n}=105)$}} & \multirow{3}{*}{ Prob. } \\
\hline & \multicolumn{2}{|c|}{ Byak $(n=51)$} & \multicolumn{2}{|c|}{ Onate $(n=26)$} & \multicolumn{2}{|c|}{ Arfak $(n=28)$} & & & \\
\hline & Mean & $\mathrm{SD}$ & Mean & $\mathrm{SD}$ & Mean & $\mathrm{SD}$ & Mean & $\mathrm{SD}$ & \\
\hline Infectious (\%) & & & 22 & 84 & & & & & \\
\hline Yes & 9 & 17 & 4 & 16 & 28 & 100 & 89 & 84 & 0.199 \\
\hline No & 42 & 83 & & & 0 & 0 & 46 & 43 & 0.199 \\
\hline $\begin{array}{l}\text { Knowledge of } \\
\text { infectious (\%) }\end{array}$ & & & 22 & 84 & & & & & \\
\hline Yes & 23 & 45 & 4 & 16 & 14 & 50 & 59 & 57 & 0.199 \\
\hline No & 28 & 55 & & & 14 & 50 & 46 & 43 & 0.199 \\
\hline Prevention (\%) & & & 22 & 84 & & & & & \\
\hline Yes & 22 & 43 & 4 & 16 & 11 & 39 & 55 & 52 & 0.223 \\
\hline No & 29 & 57 & & & 17 & 61 & 50 & 48 & 0.199 \\
\hline Mortality (heads) & & & 2.0 & 2.2 & & & & & \\
\hline Piglets & 2.3 & 1.9 & 1.3 & 1.2 & 2.4 & 2.1 & 2.2 & 2.0 & 0.199 \\
\hline Weaned & 1.9 & 1.5 & 0.88 & 0.37 & 2.3 & 2.4 & 2.0 & 1.1 & 0.199 \\
\hline PPP & 0.92 & 0.15 & 237.36 & 111.52 & 0.83 & 0.28 & 0.88 & 0.28 & 0.199 \\
\hline PPE & 222 & 88.6 & & & 289.32 & 187.87 & 234.96 & 139.49 & 0.199 \\
\hline
\end{tabular}

The Arfak pig farmers had higher number of animals (26.82 \pm 30.35 head/household) than these two tribes. Onate had $9.42 \pm 4.79$ pigs/household and Byak had 5.39 \pm 5.40 pigs/household. In detail, piglet number was higher also at Arfak tribe compared to the other two tribes, i.e. $14.25 \pm 17.47$ head /household (Arfak tribe), 3.27 \pm 4.45 pigs/household (Onate tribe) and $1.61 \pm 2.46$ pigs /household (Byak tribe). Growers raised also were significantly different $(\mathrm{P}<0.01)$. Arfak raised the highest number of growers followed by Onate and Byak, i.e. 5.61 \pm 7.69 head /household, $2.96 \pm 2.48$ head /household and 1.67 \pm 2.05 head, respectively. Similar finding was also recorded on adult pigs. There was a significant difference $(\mathrm{P}<0.01)$ between Arfak and the other two tribes. Arfak had higher adult pigs $(6.82 \pm 10.52$ head /household), Onate had $3.19 \pm 1.60$ head /household and Byak had 2.11 \pm 2.05 head /household. Byak and Onate tended to have similar number of litter size and herd size compared to Arfak. The average numbers of animals reared by these three native tribes were higher than that of Kenyan pig farmers, i.e. 3.6 head /household (Kagira et al., 2010) and in Zimbabwe (Chiduwa and Halimani, 2008).

Pig farmers have relatively the same knowledge to detect oestrous $(\mathrm{P}>0.05)$. Majority of the local pig farmers can detect oestrus, except for the Arfak. From samples of 39 Byak pig farmers $(76 \%)$ had knowledge to recognize oestrous and only 12 sample (24\%) did not know oestrous. Similar condition was encountered in Onate ethnic group. Most farmers had known in head detection of the sows and gilts. This is in line with their ages and experience of the Byak and Onate farmers.

There was no association of natural mating systems applied by the three ethnics of pig farmers $(p>0.05)$. Mating systems applied in the farm were just natural mating system. In practise, hand mating system was commonly used to 
compare to lot mating system. Farmers tended to breed sows and gilts in appropriate number compared to boars. Boars used to mating gilts and sows were belonged to other farmers. Therefore, boars were frequently rented to breed gilts and sows. Artificial insemination has not been applied yet (Table 3). In general reproduction experience practiced by swine farmers was slightly similar. Mating systems in terms of artificial insemination (AI), embryo transfers (ET) etc. have not been practiced yet. Natural mating system is the primary animal reproduction practiced in these pig farmers. In Indonesia, small-scale pig farmers apply natural mating and large-scale pig farms apply artificial insemination and embryo transfer. In Thailand (Am-in et al., 2010), AI is practiced in rural pig farming and this increases reproduction performances.

There was no association of recognizing gestating sows amongst the three ethnics of pig farmers. Additional information to detect gestating sow was based on the majority of pig farmers' experience, although, precise knowledge in pregnancy diagnosis is important. Gestation can be divided into several phases, i.e. early gestation, early to mid-gestation, mid to late gestation and late gestation.

Litter size produced by pig was significantly different $(\mathrm{P}<0.01)$. Higher number of litter size was found in Arfak tribe (9.61 $\pm 2.64 \mathrm{pigs} / \mathrm{hh})$, followed by Onate and Byak, i.e. 8.96 \pm 2.63 $\mathrm{pigs} / \mathrm{hh}$ and $1.61 \pm 2.46 \mathrm{pigs} / \mathrm{hh}$. Litter size in Thailand hillside (Nakai, 2008) was in between the tribes of Onate and Byak tribes, $7 \pm 2.1$ pigs and likewise the Byak that was lower than these two tribes. The higher amount of litter produced by Arfak tribe had any effect in amount of ration applied by this ethnic. This trend was also proven by the other two tribes which did not offer adequate amount of ration per day. Therefore, Byak and Onate should increase and improve the amount of their ration. Adult pigs need more than $3 \mathrm{~kg} /$ day, while grower, weaned and piglet need less than $3 \mathrm{~kg} /$ day.

Number of sold pigs was not significantly different. Arfak tribe sold slightly higher of piglets, grower and adults compared to Byak and Onate tribes did. They use pigs as their assets. Byak and Onate raised pigs for their secondary income activity. Mostly Byak and Onate had other sources of livelihood compared to Arfak. Arfak tribe is more agriculture specialist compared to Byak and Onate.

There was no association of selection procedures applied by the three ethnics of pig farmers. Selection procedures to obtain high quality production of pigs were done in equal number of three pig farmers' tribes. Selecting was traditionally done by looking at the high number of piglets (primiparous sows), growing rate and feeding preferences.

Performances of animal production per se and in its herds have correlation along with animal production systems (Devendra, 2006), animal genetic (Kanis et al., 2008) and strategic location where animal production are established. Animal production systems, particularly pig production, vary initially commenced from traditional to modern systems. Animal genetic has evidently played roles in creating adaptive physiological reproduction and production based on local circumstances and established pig keeping systems. This will be shown from its typical location, for instances location in adjacent of crop production and or kitchen that are abundant.

\section{Infectious Diseases}

There was no association of recognizing infectious diseases amongst the three native ethnics of pig farmers. Infectious disease was also experienced by the majority pig farmers. Arfak pig farmers had major outbreaks of infectious diseases. This due to the fact that free-range or scavenging pig farming system was very sensitive to the infection of microorganism and open air where bacteria and viruses are dispersed. Similar experience was informed by pig farmers from Kenyan (Kagira et al., 2010). Haematopinus suis and warm infestation were the most important diseases.

There was no association of knowing infectious diseases ("yes" answer and "no" answer) amongst the three ethnics of pig farmers $(\mathrm{P}>0.05)$. Several of the three ethnics of pig farmers had knowledge of infectious diseases. Byak farmers had slightly high number of not knowing infectious diseases compared to Onate and Arfak. Onate had recognized infectious diseases and sufficient knowledge in understanding the infectious diseases. Besides, Byak and Onate tended to have knowledge or experience compared to Arfak. Similar finding was reported in Kenyan free-range pig farming system by Kagira et. al. (2010).

There was no association of knowing preventing procedures of infectious diseases amongst the three ethnics of pig farmers. No 
preventions were made by Byak pig farmers (29.57\%). Byak and Onate tended to have similar number of knowledge or experience compared to Arfak. Onate pig farmers had any action to prevent infectious diseases and likewise of Arfak pig farmers.

Mortality was encountered in the sites of the three locations as well. No significant different was found between the three ethnics. Although Arfak still had the highest number piglets and weaning piglets mortality. The mortality were caused by diseases, loses and thief. Diseases reported by farmers were dysentery (blood scours), pneumonia and parasites (ring worm).

One important indicator of production systems is by measuring pig production productivity and its efficiency (Chiduwa et. al., 1996). Table 4 depicts PPP and PPE of pig keeping systems in Manokwari. The PPP was intended to measure and provide data of sold and consumed pigs with life pigs. Table 4.shown that pig production productivity (PPP) was slightly similar in these three ethnics of pig farmers. PPE wants to drawn efficiency of pigs in line with herd size productivity. High score efficiency of pig production (PPE) was achieved by ethnic Arfak $(289.32 \pm 187.87)$ and followed by Byak and Arfak. In this study, piglets were purposively taken-off due to the longevity of born pigs. These findings of PPP and PPE were similar either in ethnics of Byak, Onate and Arfak.

\section{CONCLUSION}

In general the pig farmers charactersitics were similar. Several indicators tested were age, education, objectives of rearing pigs, and species of pigs. The varies of pig farmers characteristics were experience, animal number and litter size. In line with feeding characteristics, offered feeding on each physiological period was differ. Similarities found were feeding sources and feeding process. Reproduction knowledge and experience were similar amongst the tribes. Besides, experience and knowledge at infectiouse diseases in general were similar. The similarity practices were between Byak and Onate tribes which representing islands typical pig farming systems. The different practices of pig farming components were between Byak vs Onate tribe and Arfak. Information on reproduction and productivity of the sows was utmost importance. Pig productivity and pig production efficiency of the three ethnics were similar.

\section{REFERENCES}

Am-in, N., W. Tantasuparuk and M. Thecakumphu. 2010. Comparison of artificial insemination with natural mating on smallholder farms in Thailand, and the effect of boar stimulation and distance of semen delivery on sow reproductive performance. J. Trop. Anim. Prod. 42: 921-924.

Anil, K.S., P.C. Saseendran, J. Mathew and M. Murugan. 2006. Effect of management systems on gwoth performance of two genetic groups of pigs. Tamilnadu J. Vet. Anim. Sci. 2: 229-233.

Chiduwa, G., M. Chimonyo and T.E. Halimani. 2008. Herd dynamic and contribution of indigenous pigs to the livehood of rural farmers in a semi arid area in Zimbabwe. J. Trop. Anim. Health. Prod. 40:125-136

Conroy, C.. 2005. Participatory livestock research: a Guide. ITDG Publishing. Warwickshire. United Kingdom.

Devendra, C. 2006. Perspectives on animal production systems in Asia: Review article. J. Livest. Sci. 105: 229-242.

Eusebio, J. A. 1980. Pig Production in the Tropics. Intermediate Tropical Agriculture Series. W. J. A. Payne (Ed). Longman group Ltd. Essex. United Kingdom.

Iyai, D. A. 2008. Innovation possibilities in pig keeping systems in Manokwari, West Papua. MSc- Major Thesis. Wageningen University. The Netherlands.

Iyai, D. A. 2009. Quantifying feeding regimes on weaned sows under tropical Papua pig keeping systems. MSc-Minor Thesis. Wageningen University. The Netherlands.

Iyai, D. A., B.W. I. Rahayu, I Sumpe, D. Saragih 2011. Analysis of pig profil on small-scale pig farmers in Manokwari, West Papua. J. Indonesian Trop. Anim. Agric. 36: 190-197.

Kagira, J. M., Paul W. N. Kanyari, I. Maingi, S. M. Githigia, J. T. Ng'ang'a, and J. W. Karuga. 2010. Characteristics of smallholder free range production system in Western Kenya. J. Trop. Anim. Health Prod. 42: 865873.

Kanis, E., K.H. De Greef, A. Hiemstra and J.A. M. van Arendonk. 2008. Breeding for societally important traints in pigs. J. Anim. Sci. 83: 948-957

Kumaresan, A., K. M. Bujarbaruah, K. A. Pathak, B. Chhetri, S.K. Das, A. Das and S. K. Ahmed. 2007. Performance of pigs reared 
under traditional tribal low input production system and chemical composition of nonconventional tropical plants used as pig feed. J.Livest. Sci. 107: 294-298.

Kunavongkrit, A. and T.W. Heard. 2000. Pig reproduction in South East Asia. Anim. Reprod. Sci. 60-61: 527-533.

Lemke, U., B. Kaufmann, L.T. Thuy, K. Emrich, and A.V. Zarate. 2006. Evaluation of smallholder pig production systems in North Vietnam: pig production management and pig performances. J.Livest. Sci. 105: 229243.

Nakai, S. 2008. Reproductive performance analysis of native pig smallholders in the hillside of Northern Thailand. J. Trop. Anim. Health Prod. 40:561-566

Ott, R.L. and M. Longnecker. 2001. An Introduction to Statistical Methods and Data Analysis. $5^{\text {th }}$ Edition. Texas A \& M
University. Wadsworht Group USA.

Pattiselanno, F. and D. A. Iyai, 2005. Peternakan babi di Manokwari; mempertahankan tradisi dan meningkatkan taraf hidup. Salam. No.13. December 2005.

Perkins, R. 2002. Priorities for pigs research in Southeast Asia and the Pacific to 2010. ACIAR Working Paper No. 53. March 2002. Australian Centre for International Agriculture Research. Canberra. Australia.

Randa, S.Y. 1994. Performance of indigenous pigs of upland and lowland Irian Jaya. Thesis. Department of Animal Science. Los Baños, The Philippines.

Snedecor, G.W. and W.G. Cochran. 1989. Statistical methods. $8^{\text {th }}$ Edition. Iowa State University Press. United States of America.

Udo H. M. J. 1997.Relevance of farmyard animals to rural development.Outlook on agriculture. 26: $25-28$ 